\title{
Investigations of stretch and recovery properties of knitted socks
}

\author{
DOI: 10.35530/IT.071.02.1671
}

SIKANDER ABBAS BASRA

NORINA ASFAND

ABDUL WAQAR RAJPUT

ZEESHAN AZAM

BILAL ZAHID

HAFSA JAMSHAID

\section{ABSTRACT - REZUMAT}

\section{Investigations of stretch and recovery properties of knitted socks}

Knitted fabrics are renowned for stretch properties which owe to their comfort properties such as formability, fitting to the human body and shape retention after wearing. Optimum stretch is basic requirement in knitted socks to support blood flow in legs and feet. This stretch is achieved with fabric structure type and material used in it. Different factors affect the stretch and recovery of sock, but most contributing factors are elastane percentage, main yarn material and finishing process type. Four different percentages of elastane in plaiting (4\%, 6\%, 8\% and 10\%), two main yarns materials (Cotton and Polyester/Cotton PC), and two finishing process types(Wash and bleach) were taken as level of input variables to study their effect on stretch and recovery. Stretch and recovery tests were performed on knitted sock tube. After testing, Minitab software was used for analysis of variance of obtained results using full factorial design. Significance of all factors and levels was analyzed. It was found that with the increase in elastane percentage stretch was decreased and recovery was increased. Cotton was found to have less stretch and more recovery percentage as compared to PC. Additionally it was observed that washing treatment produced significantly higher stretch and lesser recovery than bleaching. Similar trend was also observed in interaction plot indicating that all variables were dependent on each other.

Keywords: socks, elastane percentage, cotton, polyester/cotton PC, stretch, recovery, full factorial design

Analiza proprietăților de întindere și revenire din întindere ale șosetelor tricotate

Materialele textile tricotate sunt renumite pentru proprietățile de întindere, care conferă și proprietăți de confort, cum ar fi formabilitatea, potrivirea pe corpul uman și păstrarea formei după purtare. Întinderea optimă este o cerință de bază la șosetele tricotate pentru a susține fluxul de sânge în membrele inferioare. Această întindere se obține prin structura tricotului și materia primă utilizată. Diferiți factori influențează întinderea și revenirea din întindere a șosetei, dar cei mai importanți sunt procentul de elastan, materia primă principală a firului și tipul procesului de finisare. Patru procente diferite de elastan (4\%,6\%, 8\% și 10\%), două materii prime principale ale firului (bumbac și poliester/bumbac PC) și două tipuri de procedee de finisare (spălare și albire) au reprezentat variabilele de intrare pentru a studia influența lor asupra întinderii și revenirii din întindere. Au fost efectuate teste de întindere și revenire din întindere pentru şosetele tricotate tubular. După testare, software-ul Minitab a fost utilizat pentru analiza variației rezultatelor obținute aplicând modelul factorial complet. Astfel, a fost analizată semnificația tuturor factorilor și nivelurilor. S-a constatat că odată cu creșterea procentului de elastan a scăzut nivelul de întindere, iar revenirea din întindere a crescut. S-a constatat că bumbacul prezintă un nivel mai redus de întindere și o revenire mai mare din întindere în comparație cu PC. În plus, s-a observat că tratamentul de spălare a produs o întindere semnificativ mai mare și o revenire din întindere mai mică decât albirea. O tendință similară a fost observată și în graficul de interacțiune care indică faptul că toate variabilele erau dependente unele față de altele.

Cuvinte-cheie: șosete, procent de elastan, bumbac, poliester/bumbac PC, întindere, revenire din întindere, model factorial complet

\section{INTRODUCTION}

Knitted fabrics provide excellent comfort properties. These fabrics are preferred in many kinds of clothing due to their superior properties. Knitted fabrics are produced on different machines with combinations of different type of stitches and color combinations to create different patterns and fabric types [1]. Knitted socks are designed to provide comfort, absorb and evaporate sweat, protect foot, warm/cool the foot or as a fashion. Parts of socks may be welt, leg, ankle, high heel, heel, foot, arch support, and toe. Types of yarns being used in sock are main yarn, plaiting yarn, elastic yarn/gripping yarn, motif yarn/pattern yarn, splicing yarn and technical yarn [2]. In elastic contents of yarn, a soft and flexible segment (polyester/ polyether/polyols) is bonded with rigid and hard segments (urethane) and technically termed as segmented polyurethane. This composition provides the lasting and built in stretch to the fiber [3-4]. The stretch of a fabric can be defined as "the strain produced in a specimen of fabric on application of stress under specific conditions" (equation 1).

Fabric stretch \% =

$=$ Increase in length of a specimen on tension Original length prior to tension force 
The work recovery of the fabric can be defined as "ratio of the recovered elastic energy and the total tensile energy applied for the specific strain" (equation 2).

$$
\begin{gathered}
\text { Fabric recovery } \%= \\
=\frac{\text { Tensile energy (unloading) }}{\text { Tensile energy loading }} \times 100
\end{gathered}
$$

Senthilkumar M. and Anbumani N. studied the effect of different extension levels on stretch and recovery properties of garment during body movements. They concluded that the spandex plaited cotton fabric showed higher elastic recovery as compared to core spun spandex with cotton fabrics [5]. Serkan Tezel et al. investigated the effect of elastane on properties of single jersey fabric developed with cotton and spandex. It was concluded that elastane significantly influenced the properties of fabric since spandex brands with higher tension give highest weight, high thickness and stitch density. The presence of spandex, however reduced the air permeability of the fabric as compared to $100 \%$ cotton fabric [6]. Burji M. et al. investigated that spandex back plaiting increases stretchability and elastic recovery of the fabric more than core cotton spun fabric and hence are more suitable for sportswear. It also exerts more pressure on body than core spun with yarn [7]. Bilal Qadir et al. concluded that the fabric stretchability and recovery after stretch increases with higher denier elastane in core-spun cotton yarn. They also concluded that increase in elastane draft ratio enhanced the stretch-ability and reduced the recovery after stretch [8]. Lukkassen D. et al. investigated the effect of polyester and nylon on properties of sportswear fabrics. They concluded that polyester and nylon showed exceptional, dimensional stability, optimum strength, high stretch and recovery properties. It was also found that these yarns had excellent abrasion resistance and resistance to dirt, decay and mould in sportswear [9]. Senthilkumar, and N. Anbumani, investigated stretch and recovery properties of the cotton/spandex knitted fabric. They found that with the increase of spandex linear density, stretch and recovery of the fabric increases. It was also studied that dynamic work recovery of the fabric at greige stage is higher which decreased after heat setting and bleaching but after compaction dynamic work recovery of the fabric was slightly increased [10]. Saber Ben Abdessalem et al. studied the relation between Lycra ${ }^{\circledR}$ consumption and fabric dimensional and elastic behaviour. In cotton Lycra ${ }^{\circledR}$ blend with increased tension on Lycra ${ }^{\circledR}$ yarn decreased the consumption of Lycra ${ }^{\circledR}$ and hence decreased the width of the fabric. Furthermore, the fabric recovery also decreased with the decrease in Lycra ${ }^{\circledR}$ consumption [11].

As per knowledge of this author, stretch and recovery behaviour of different knitted fabrics i.e. single jersey, rib, interlock, fleece had been studied earlier but no significant research has been carried out on socks to sort out the problem of uneven stretch and recovery keeping in view the elastane percentage and finishing process applications. Hence, this study provides better understanding of the effect of different variables on stretch and recovery properties of socks. In this research, different percentages of elastane and different finishing processes were applied on plain plaiting knitted socks on a same gauge and their stretch and recovery properties have been studied. Objectives of this research are to investigate the effect of elastane percentage, main yarn type and finishing process type on stretch and recovery percentage in length and width of welt and foot by using Full Factorial Design method and analysis of variance (ANOVA) statistical approaches.

\section{MATERIAL AND METHODS}

This study was focused to investigate the stretch and recovery properties of plaited knitted socks on the basis of the $70 \mathrm{D} 24$ filaments nylon covered elastane percentage $(4 \%, 6 \%, 8 \%$, and $10 \%)$ in core and the type of main yarns used were $20 \mathrm{Ne}$ Cotton and 20 Ne Polyester/Cotton. Total sixteen samples were developed with combination of these yarns with washing and bleaching. Design of experiment is given in table 1. Full factorial experiments are the ones where investigation of the impact of greater than one factors over response is carried out. Also, the number of experiments geometrically increases with the increasing number of factors and levels [12-13].

Samples were developed on 14E knitting machine. In welt and foot elastic inlaid plaited and plain plaited fabric structures were developed respectively. Samples relaxed in the standard atmosphere of $20 \pm 2^{\circ} \mathrm{C}$ and $65 \pm 4 \%$ relative humidity for 24 hours

Table 1

\begin{tabular}{|c|c|c|c|}
\hline \multicolumn{4}{|c|}{ DESIGN OF EXPERIMENT } \\
\hline \multirow{2}{*}{ Run } & \multicolumn{3}{|c|}{ Factors } \\
\cline { 2 - 4 } & Plaiting yarn & Main yarn & $\begin{array}{c}\text { Finishing } \\
\text { process }\end{array}$ \\
\hline 1 & Nylon with Elastane 4\% & Cotton 100\% & Wash \\
\hline 2 & Nylon with Elastane 6\% & Cotton 100\% & Wash \\
\hline 3 & Nylon with Elastane 8\% & Cotton 100\% & Wash \\
\hline 4 & Nylon with Elastane 10\% & Cotton 100\% & Wash \\
\hline 5 & Nylon with Elastane 4\% & PC 52:48 & Wash \\
\hline 6 & Nylon with Elastane 6\% & PC 52:48 & Wash \\
\hline 7 & Nylon with Elastane 8\% & PC 52:48 & Wash \\
\hline 8 & Nylon with Elastane 10\% & PC 52:48 & Wash \\
\hline 9 & Nylon with Elastane 4\% & Cotton 100\% & Bleach \\
\hline 10 & Nylon with Elastane 6\% & Cotton 100\% & Bleach \\
\hline 11 & Nylon with Elastane 8\% & Cotton 100\% & Bleach \\
\hline 12 & Nylon with Elastane 10\% & Cotton 100\% & Bleach \\
\hline 13 & Nylon with Elastane 4\% & PC 52:48 & Bleach \\
\hline 14 & Nylon with Elastane 6\% & PC 52:48 & Bleach \\
\hline 15 & Nylon with Elastane 8\% & PC 52:48 & Bleach \\
\hline 16 & Nylon with Elastane 10\% & PC 52:48 & Bleach \\
\hline
\end{tabular}




\begin{tabular}{|c|c|c|c|c|c|}
\hline \multicolumn{7}{|c|}{ KNITTING PARAMETERS OF PLAIN PLATED FABRIC } \\
\hline $\begin{array}{c}\text { Course per unit } \\
\text { area }\left(\mathbf{c m}^{-1}\right)\end{array}$ & $\begin{array}{c}\text { Wales per unit } \\
\text { area }\left(\mathbf{c m}^{-1}\right)\end{array}$ & $\begin{array}{c}\text { Stitch density } \mathbf{~ p e r} \\
\text { unit area }\left(\mathbf{c m}^{-2}\right)\end{array}$ & $\begin{array}{c}\text { Stitch length } \\
(\mathbf{m m})\end{array}$ & $\begin{array}{c}\mathbf{R} \\
\left(\mathbf{K}_{\mathbf{c}} / \mathbf{K}_{\mathbf{w}}\right)\end{array}$ & $\begin{array}{c}\text { Tightness factor } \\
(\sqrt{\text { Tex}} / \mathbf{S L})\end{array}$ \\
\hline 12.6 & 9.06 & 114.08 & 5.3 & 1.39 & 10.25 \\
\hline
\end{tabular}

for dry relaxation. Knitted fabric parameters were determined according to standard test methods. Welt length was adjusted at $3 \mathrm{~cm}$ and welt width was adjusted at $8 \mathrm{~cm}$ on knitting machine for all samples. Foot length and width was also adjusted on knitting machine for all samples at 17 and $10 \mathrm{~cm}$ respectively. All the knitting parameters were verified according to standard tests method ASTM D3887. Parameters of plain plated knitted fabric are given in table 2 .

Wash and bleach finishing processes were applied on these samples after conditioning and evaluation of parameters. After washing and bleaching, steam was applied for 20 minutes for tumble drying and re-conditioning was done at standard atmosphere of $20 \pm 2^{\circ} \mathrm{C}$ and $65 \pm 4 \%$ relative humidity for 24 hours for dry relaxation. Stretch and recovery percentage was measured according to ASTM D2594-99a standard test method. Percentage Stretch of welt and foot was calculated on stretch equipment (CETME specifically used for sock). CETME tester was used to determine dimensional changes. Specimens were fixed between two jaws in width direction and lever holding these jaws were dropped down manually at standard carriage weight of $4.65 \mathrm{Kgs}$.

The results were analyzed by ANOVA with the help of Minitab software. Full factorial design was selected for data analysis. ANOVA was performed in order to determine the statistical significance of experimental factors i.e. effect of elastane percentage in plaiting yarn, fiber type in main yarn, type of finishing process against their response variables i.e stretch and recovery of socks parts, at 95\% confidence level. Due to the $95 \%$ confidence interval, the parameters with $\mathrm{P}<0.05$ values indicate that the effect of that parameter on the given experimental layout is statistically significant. Interaction plot also studied to find out dependency level of input variables.

\section{RESULTS AND DISCUSSIONS}

Effect of input variables were studied on stretch and recovery properties of socks. After washing and bleaching, stretch and recovery percentage in welt width and foot width was calculated. Five specimens of each sample were taken for each measurement. Standard deviation and mean values of measurements were calculated. Effect of experimental variables on stretch and recovery is given in table 3 .

\section{Impact on stretch percentage of welt width}

Effect of elastane in plaiting yarn was found with significant effect $(p$-value $=0.005$ ) on stretch percentage of welt width. Main yarn type has a statistically significant ( $p$-value $=0.022$ ) effect with $95 \%$ confidence. Finishing process type i.e bleaching and

Table 3

\begin{tabular}{|c|c|c|c|c|c|c|c|c|}
\hline \multicolumn{9}{|c|}{ EFFECT OF EXPERIMENTAL VARIABLES ON STRETCH AND RECOVERY PROPERTIES } \\
\hline \multirow{2}{*}{$\begin{array}{c}\text { Sample } \\
\text { no. }\end{array}$} & \multicolumn{2}{|c|}{ Welt Stretch (\%) } & \multicolumn{2}{|c|}{ Foot Stretch (\%) } & \multicolumn{2}{|c|}{ Welt Recovery (\%) } & \multicolumn{2}{|c|}{ Foot Recovery (\%) } \\
\hline & Mean & S.D & Mean & S.D & Mean & S.D & Mean & S.D \\
\hline 1 & 209.38 & 0.44 & 142.50 & 0.00 & 86.75 & 0.20 & 85.14 & 0.10 \\
\hline 2 & 206.25 & 2.21 & 140.20 & 0.45 & 89.15 & 0.16 & 91.03 & 0.13 \\
\hline 3 & 202.75 & 2.85 & 135.90 & 1.24 & 92.65 & 0.12 & 91.86 & 0.12 \\
\hline 4 & 200.63 & 2.25 & 138.00 & 1.17 & 94.53 & 0.16 & 92.74 & 0.12 \\
\hline 5 & 212.50 & 0.88 & 150.40 & 0.55 & 82.00 & 0.25 & 80.09 & 0.15 \\
\hline 6 & 208.88 & 2.52 & 147.50 & 0.35 & 83.39 & 0.17 & 81.19 & 0.09 \\
\hline 7 & 208.00 & 1.90 & 145.00 & 0.00 & 86.31 & 0.19 & 84.68 & 0.06 \\
\hline 8 & 206.13 & 1.79 & 140.20 & 0.45 & 87.76 & 0.19 & 86.05 & 0.12 \\
\hline 9 & 192.75 & 1.37 & 110.00 & 0.71 & 85.24 & 0.15 & 84.50 & 1.37 \\
\hline 10 & 190.63 & 0.44 & 115.00 & 0.71 & 89.09 & 0.18 & 87.25 & 2.93 \\
\hline 11 & 189.00 & 2.01 & 110.00 & 0.71 & 93.16 & 0.17 & 89.75 & 0.44 \\
\hline 12 & 188.25 & 3.57 & 100.20 & 0.84 & 95.91 & 0.19 & 92.15 & 1.79 \\
\hline 13 & 193.25 & 0.68 & 117.60 & 0.22 & 83.60 & 0.18 & 85.25 & 0.56 \\
\hline 14 & 190.00 & 2.93 & 112.50 & 0.35 & 87.08 & 0.23 & 88.23 & 1.90 \\
\hline 15 & 187.88 & 3.41 & 110.40 & 0.55 & 89.79 & 0.12 & 90.20 & 0.68 \\
\hline 16 & 187.75 & 0.56 & 102.50 & 0.35 & 93.22 & 0.12 & 94.20 & 0.44 \\
\hline
\end{tabular}


washing has significant impact on stretch percentage of welt width of sock ( $p$-value $=0.00)$. The degree of stretch depends on the amount and type of elastane incorporated for construction of the fabric [6]. In weft knitted structures, interlocking of loops can be pulled and stretched in different directions giving the knitted fabrics a higher degree of stretch. Low percentage of elastane contained more crimp per unit area as compared to higher percentage of elastane in covered yarn. High crimps in nylon yarn due to drafted elastane produced higher stretch in welt width. With application of load, high crimp yarn causes more increase in yarn length as compare to low crimp covered yarn. In nylon, where less elastane $\%$ is used as sheath leads to increase in tension of yarn, decreases the consumption of elastane. Due to this, width of the fabric decreases and stretch \% increases [8]. That's why stretch of $4 \%$ elastane covered nylon socks is higher as compared to $6 \%, 8 \%$ and $10 \%$. Slacker fabrics have higher stretch as compared to denser fabric. A Mukhopadhyay et.al.in their research concluded that, fabric made with elastane covered yarn, the immediate recovery, extension and resiliency are higher but delayed recovery and permanent set are lower than those of $100 \%$ spun or filament yarn fabrics [15]. In bleaching the stretch of fabric was reduced due to increase in stitch density as shown in figure 1. Cotton leads high shrinkage as compare to polyester/cotton yarn. The stretch percentage was decreased due to compactness of cotton main yarn as compared to polyester/cotton yarn. In $100 \%$ of cotton yarns, fiber-to-fiber frictions are superior to fiber-to-fiber friction in cotton and polyester in PCs that reduce stretching.

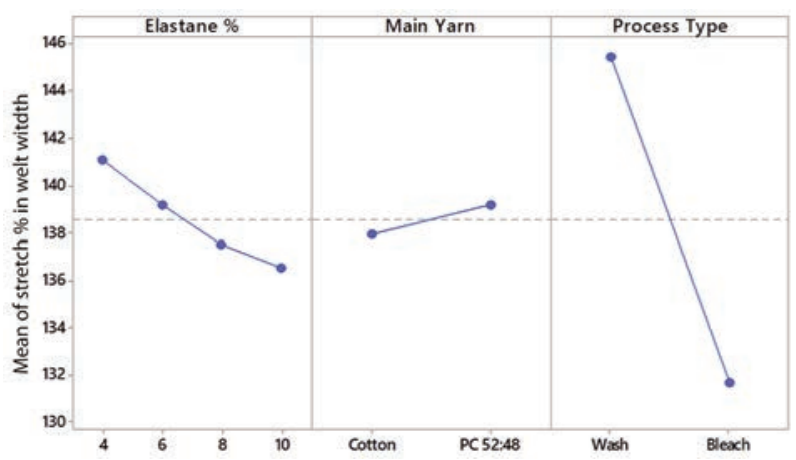

Fig. 1. Main effect plot for stretch in welt width

\section{Impact on stretch percentage of foot width}

Effect of elastane in plaiting yarn was found having significant effect $(p$-value $=0.039)$ on stretch percentage of foot width. Main yarn type has a statistically significant $(p$-value $=0.048$ ) effect with 95\% confidence. Finishing processing type, bleaching and washing has significant impact on stretch percentage of foot width of sock ( $p$-value $=0.00)$. Elastane fibers consist of soft (flexible) segments bonded together with hard segments giving the fiber a built-in stretch. In weft knitted structures, the yarns follow a meandering path forming systematic loops above and below the mean path of the yarn systematically. These interlocking of loops can be pulled and stretched in different directions giving the knitted fabrics a higher degree of stretch. Nylon covering with low percentage of elastane contained high crimp; these crimps increased the stretch percentage of foot width. In the nylon elastane, the increased tension in the elastane yarn decreases the elastane consumption and, therefore, decreases the width of the fabric and increases the stretch [8]. That is why the stretch of $4 \%$ elastane covered knitted nylon socks is higher compared to $6 \%, 8 \%$ and $10 \%$. Higher percentage carry small crimps on nylon that's why higher percentages of elastane in covered yarn has less stretch percentage as shown in figure 2. Washed sample showed higher stretch percentage due to less shrinkage percentage as compared to bleached samples. Shrinkage percentage in cotton samples was higher as compare to PC. PC socks also carried higher stretch as compared $100 \%$ cotton respectively due to slacker knitted fabrics less compactness. In $100 \%$ cotton yarn fibre to fibre frictions are higher as compare to fibre to fibre friction of cotton and polyester in $\mathrm{PC}$ which reduces stretch.

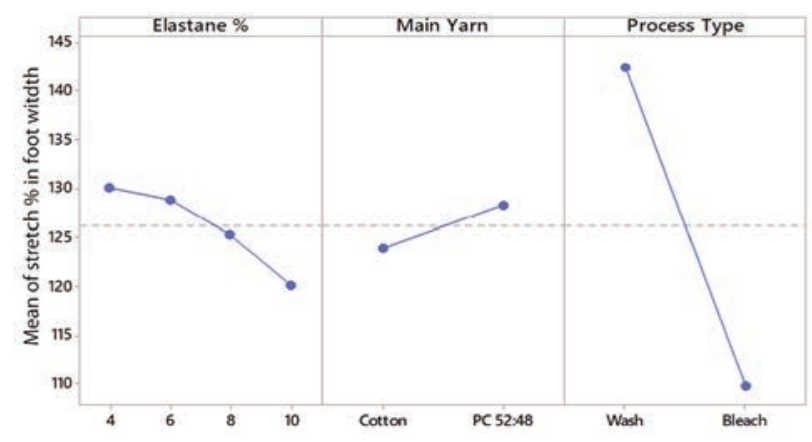

Fig. 2. Main effect plot for foot width

\section{Impact on recovery percentage of welt width}

Effect of elastane in plaiting yarn was found with significant effect of $(p$-value $=0.00)$ on recovery percentage of welt width. Main yarn type has a statistically significant ( $p$-value $=0.00$ ) effect with 95\% confidence. Finishing processing type, bleaching and washing has significant impact on recovery percentage of welt width of sock ( $p$-value $=0.00)$. The recovery percentage increased with increase in elastane percentage as shown in figure 3 . This is due to presence of highly elastic yarn offering less frictional contact between interlocking points of loops. Higher the compactness of fabric more will be its ability to generate and maintain pressure. Loops will tend to revert to its original shape and position as soon as the mechanical stresses were removed from fabric. This may be due to decrease in tenacity of elastane. In elastane covered with nylon, the increased tension in the elastane thread reduces the consumption of elastane and, therefore, the width of the fabric reduces and the recovery of the fabric also decreases with the decrease in elastane consumption. When the extension ratio increases, the plastic extension increases 
and elasticity decreases and, as a result, elastic recovery decreases [14]. Cotton shows higher recovery percentage as compared to polyester/cotton due to jamming of loops. Higher shrinkage reduces area of fabric which recovered easily as compare to slacker fabrics. That's why recovery of cotton and bleached fabrics were higher as compare to PC and washed samples respectively. Dynamic work recovery of the fabric at grey stage is higher which decreased after heat setting and bleaching but after compaction dynamic work recovery of the fabric found to be increased somewhat [16]. Bleaching showed higher recovery percentage as compared to washing due to interlocking of loops during bleaching process as shown in figure 3.

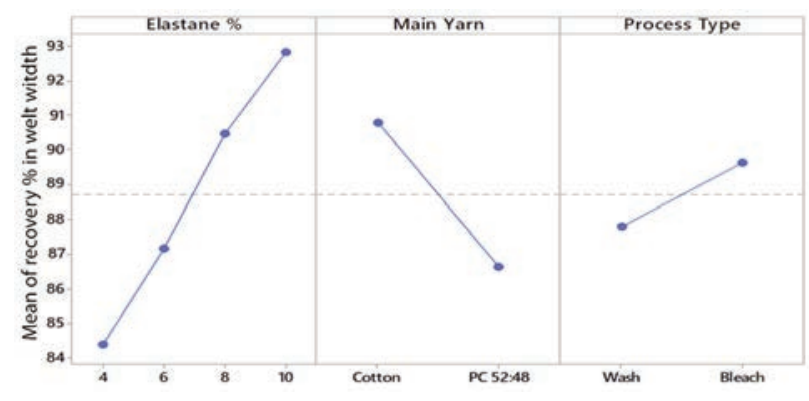

Fig. 3. Main effect plot for welt width

\section{Impact on recovery percentage of foot width}

Effect of elastane in plaiting yarn on recovery percentage of foot width was found significant ( $p$-value = 0.007 ). Main yarn type has a statistically significant ( $p$-value $=0.010)$ effect with 95\% confidence. Finishing processing type, bleaching and washing has significant impact on recovery percentage of foot width of sock $(p-v a l u e=0.021)$. In nylon covered elastane with increased tension on elastane yarn decreases the consumption of elastane and hence decreases the width of the fabric and fabric recovery also decreases with decrease in elastane consumption. When the extension ratio increases the plastic extension increases and the elastic one decreases and consequently the elastic recovery decreases
[14]. Fabric compactness increased with increase in stitch density of fabric. Higher the compactness of fabric more will be its ability to generate and maintain pressure. Greater shrinkage reduces the area of easily recoverable as compared to slacker fabrics. Therefore recovery of cotton and bleached fabrics was higher than that of PC and washed samples. The dynamic recovery of the work of the fabric in the gray stage is greater, which decreased after the thermal setting and the discoloration, but after the compaction, the dynamic recovery of the work of the fabric increased a bit [16]. Recovery percentage of foot width was increased in bleached due to higher retracting force of fabric loops towards recovery due to higher stitch density as shown in figure 4.

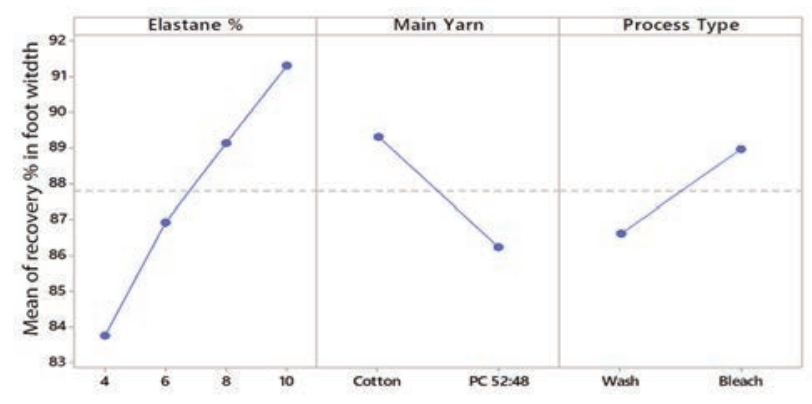

Fig. 4. Main effect plot for foot width

\section{CONCLUSION}

It was found that with the increase in elastane percentage, stretch was decreased in welt and foot. Cotton was found to have less stretch as compared to PC. Additionally it was observed that washing treatment produced significantly higher stretch than bleaching. In stretch percentage all variables are dependent on each other.

The recovery percentage increased with increase in elastane percentage in both welt and foot. Cotton has higher recovery percentage as compared to $\mathrm{PC}$ and bleaching process showed higher recovery percentage as compared to washing. It was also observed in interaction plot that all variables are dependent on each other.

\section{REFERENCES}

[1] Sadhan Chandra, R., Fundamentals and advances in knitting technology, WPI Publishing, 2012

[2] Anastsopoulos, M., Totham, D., Van Veen, A., Jones, J., US 2009/0044313 A1 United States of America, 2009

[3] Fiori, S., Mariani, A., Ricco, L., Russo, S., First synthesis of a polyurethane by frontal polymerization, In: Macromolecules, 2003, 2674-2679

[4] Krol, P., Synthesis methods, chemical structures and phase structures of linear polyurethanes. Properties and applications of linear polyurethanes in polyurethane elastomers, copolymers and ionomers, In: Progress in materials science, 2007, 915-1015

[5] Senthilkumar, M., Anbumani, N., Dynamics of Elastic Knitted Fabrics for Sports Wear, In: Textile Research Journal, 2011, 13-25

[6] Tezel, S., Kavuşturan, Y., Experimental Investigation of Effects of Spandex Brand and Tightness Factor on Dimensional and Physical Properties of Cotton/Spandex Single Jersey Fabrics, In: Textile Research Journal, 2008, 966-976

[7] Burji, M., Kadole, P.V., Lokesh, K.V., Effect of twist levels in polyester yarn on elastic behavior of polyester/spandex air covered yarn, Melliand International, 2015

[8] Qadir, B., Hussain, T., Malik, M., Effect of Elastane Denier and Draft Ratio of Core-Spun Cotton Weft Yarns on the Mechanical Properties of Woven Fabrics, In: Journal of Engineered Fabrics and Fibers, 2014 
[9] Lukkassen, D., Meidell, A., Advanced materials and structures and their fabrication processes, Narrik University College, 2003

[10] Senthilkumar, S.S.M., Anbumani, N., Effect of Spandex Input Tension, Spandex Linear Density and Cotton Yarn Loop Length on Dynamic Elastic Behavior of Cotton/Spandex Knitted Fabrics, In: Journel Text. Apparel, Technol. Manag, 2012

[11] Ben Abdelkader, Y., Mokhtar, S., Elmarzougui, S., Influence of Elastane Consumption on Plated Plain Knitted Fabric Characteristics, Saber Ben Abdessalem, 2010

[12] Kavak, D.N., Boron removal from aqueous solutions by adsorption on waste sepiolite and activated waste sepiolite using full factorial design, In: Adsorption, 2004, 245-257

[13] Hande Sezgin, S.K., Thermal analysis of e-textile structures using full-factorial experimental design method, In: Journal of Industrial Textiles, 2014, 752-764

[14] Helali, H., Babay Dhouib, A., Msahli, S., Cheikhrouhou, M., Influence of Dorlastan® draft and yarn count on the elastic recovery of the Dorlastan $\AA$ core spun yarns following cyclic test, In: The Journal of the Textile Institute, 2012, 378-384

[15] Mukhopadhyay, A., Sharma, I.C., Mohanty, A., Impact of lycra filament on extension and recovery characteristics of cotton knitted fabrics, In: Indian Journal of Fibre and Textile Research, 2003, 423-430

[16] Pérez-Soriano, P., García-Roig, Á., Sanchis-Sanchis, R., Influence of compression sportswear on recovery and performance: A systematic review, In: Journal of Industrial Textiles, 2018, 1505-1524

Authors:

SIKANDER ABBAS BASRA ${ }^{1}$, ABDUL WAQAR RAJPUT², BILAL ZAHID ${ }^{3}$, NORINA ASFAND ${ }^{1}$, ZEESHAN AZAM ${ }^{1}$, HAFSA JAMSHAID ${ }^{1}$

${ }^{1}$ Protective Textile Research Group, Faculty of Engineering \& Technology, National Textile University, Pakistan e-mail: basra.ntu@gmail.com, norina892@gmail.com, zeeshanazam250@gmail.com

${ }^{2}$ Technical Textile Research Group, BZU College of Textile Engineering, Multan, Pakistan e-mail: waqar.rajput@bzu.edu.pk

${ }^{3}$ Textile Engineering Department, NED University of Engineering and Technology, Karachi - 75270, Sindh, Pakistan

e-mail: drbilalzahid@neduet.edu.pk

Corresponding author:

HAFSA JAMSHAID

email: hafsa@ntu.edu.pk 